ノート・ Note

\title{
窒化ケイ素セラミックスのメタライズ法
}

\author{
江畑儀弘 - 玉利信幸 -木下 実 - 速水諒三 \\ (大阪工業技術試験所) \\ (1983 年 10 月 3 日受付)
}

\section{Metallizing Technique for Silicon Nitride Ceramics}

\author{
Yoshihiro EBATA, Nobuyuki TAMARI, Makoto KINOSHITA and Ryozo HAYAMI \\ (Government Industrial Research Institute, Osaka) \\ Midorigaoka 1-chome, Ikeda-shi 56
}

[Received October 3, 1983]

Key-words : Metallizing, Cupric sulfide, Silicon nitride

\section{1. 緒 言}

窒化ケイ素や炭化ケイ素等の非酸化物セラミックスは 高強度であるとともに，耐熱性，耐摩耗性に優れている ため，ガスタービンや自動車エンジンなどの高温構造材 としてクローズアップされている。これらのセラミック スを各種の装置や機械に活用しようとする場合，セラ ミックス自体の成形加工の制約から，単純な形に成形さ れた部材から，上り複雑な形の部材に組み立てる必要が あり，七ラミックス材料の接着技術の確立が望まれる.

著者らは，従来から酸化物セラミックスのメタライズ について研究を進め, 硫化銅 (CuS) とカオリンの混合 物を大気中で加熱するだけでセラミックス表面にメタラ イズできることを報告してきたが(1) 4)，今回，同様な方 法により $\mathrm{Si}_{3} \mathrm{~N}_{4}$ のメタライズが可能であることが認めら れたのでここに報告する.

\section{2. 実験}

用いた窒化ケイ素は常圧焼結品（日本特殊陶業社製, $\mathrm{Al}_{2} \mathrm{O}_{3}$ などを $10 \mathrm{wt} \%$ 含む，気孔率 $\left.1 \%\right)$ で，試料の寸 法は $13 \times 13 \times 7 \mathrm{~mm}^{3}$ である．接着剂成分の硫化銅は試 薬 1 級を,カオリンは市販の関白カオリンを用いた. 硫化 銅とカオリンを粘結剤（スクリーンオイル）と一緒に十 分に混練してペースト状にした。表 1 に硫化銅とカオリ ンの混合比を示す。このペーストを試料表面に $0.2 \mathrm{~mm}$ 厚に塗布した後, 乾燥し, $1100^{\circ} \mathrm{C}$ の電気炬に入れ，空 気中で 15〜30 分加焼して焼きつけた。これを $300^{\circ}$ $500^{\circ} \mathrm{C}$ にしてエチルアルコール中に投入し，表面を還元 して金属銅にした。

これに銅板を高融点はんだを用いてろう接し，更に銅
Table 1. Mixing ratio between $\mathrm{CuS}$ and kaolin (wt\%).

\begin{tabular}{|c|c|r|r|r|c|}
\hline Sample & 1 & 2 & 3 & 4 & 5 \\
\hline CuS & 100 & 95 & 90 & 80 & 50 \\
\hline Kaolin & 0 & 5 & 10 & 20 & 50 \\
\hline
\end{tabular}

ホルダーをはんだ付けして引っ張り強度を測定した (引っ張り速度 : $5 \mathrm{~mm} / \mathrm{min}$ ). また, 試料断面の顕微 鏡及び EPMA 観察を行った. 別に接着剂ペレットを窒 化ケイ素板に重ねて加熱したものについて表面から削り 取りながら X 線回折を行った。

\section{3. 結果と考察}

上記試料について引つ張り強度を測定した結果, 全体 として強度は 8 13 MPaであり, カオリンの量の多い 方が強度が大きくなる傾向が認められた。このようにカ オリン量が多いほど強度が大きくなるのは，カオリンを 混入することによりガラス化する量が増えるので窒化ケ イ素に対する接着剤の需れ性が良くなるためと考えられ る。また，破壊個所は必ずしも一定せず，接着剤層とろ う接層の界面あるいは接着㓮層と窒化ケ亿素基板の界面 ではく離したり，たまには接着剤層内部から破壊した。 次に, 接着剤表面の電気抵抗值を測定した。加熱して焼 き付けたままの状態では $2 \times 10^{9} \Omega$ 程度であったが，工 チルアルコールで還元後はいずれの試料でもほぼ 0 に なった。

試料 1 及び 3 の組成分を径 $10 \mathrm{~mm}$, 厚さ $1 \mathrm{~mm}$ のペ レット状にし，窒化ケイ素板上に置いて加熱したものに ついて, ペレット表面, 中間, 窒化ケイ素界面と順に研 
Table 2. X-ray diffraction of metallized layer above $\mathrm{Si}_{3} \mathrm{~N}_{4}$ substrate.

\begin{tabular}{|c|l|l|l|}
\hline Sample & $\begin{array}{l}\text { Surface of } \\
\text { metallized } \\
\text { layer }\end{array}$ & $\begin{array}{l}\text { Metallized } \\
\text { layer }\end{array}$ & $\begin{array}{l}\text { Interface between } \\
\text { metallized layex } \\
\text { and } \mathrm{Si}_{3}{ }_{4}\end{array}$ \\
\hline 1,3 & $\mathrm{Cu}_{2} \mathrm{O}, \mathrm{CuO}$ & $\begin{array}{l}\mathrm{Cu}_{2} \mathrm{O}, \mathrm{Cu} \\
\mathrm{CuO}\end{array}$ & $\begin{array}{l}\mathrm{(SN}), \mathrm{SiO}_{2} \text { cryst. } \\
\mathrm{Cu}_{2} \mathrm{O} \approx \mathrm{CuO}\end{array}$ \\
\hline
\end{tabular}

削した試料のX線回折結果を表 2 に示す，量的に多い と思われるものから順に並へてある。.試料 3 と試料 1 で生 成相に差異は見られず, カオリン添加による別種の結晶 の析出は検出されなかった。なお，硫化銅は加熱処理に より酸化銅 $\left(\mathrm{CuO}, \mathrm{Cu}_{2} \mathrm{O}\right)$ 及び金属銅に変化している ことを認めた。

図 1 に試料 1 及び試料 3 の接着剂層断面の光学顕微鏡 写真を示す。両試料とも窒化ケイ素基板上には透明な層 があり，接着殽層内部には樹枝状の結晶が成長している. また，大きな結晶の間に小さな結晶も多数見られる。試 料 1 の場合, 窒化ケイ素と接着剛の間に気泡が多数存在 するが，試料 3 につては気泡が少ない。この結果から もカオリン添加は濡れ性の改善に役立っていることが分 加る。図 2 に試料 3 の接着剂層の EPMA 観察の結果を

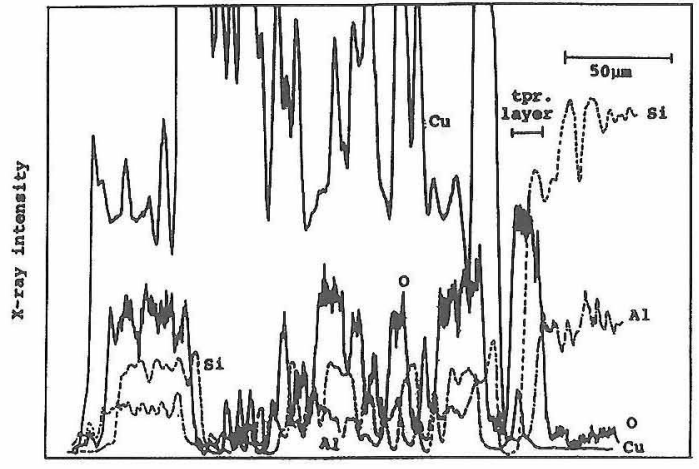

Fig. 2. EPMA trace of metallized layer of sample 3. The right hand is $\mathrm{Si}_{3} \mathrm{~N}_{4}$ substrate. The range of bar shows the transparent layer.

部分的に金属銅になる。䇪化ケイ素基板は酸化して， $\mathrm{SiO}_{2}$ 及び $\mathrm{Al}_{2} \mathrm{O}_{3}$ は接着剤中に溶け込むが，界面に $\mathrm{SiO}_{2}$ 層を形成する，基板の酸化により発生するガスは抜けに くく，界面に残る．力オリンを添加した場合は，力オリ ンがフラックス的に働き，基板と接着剤との濡れを良く し，発生したガスも比較的良く拢ける，それ以外は硫化 銅のみの場合とほぼ同じである。
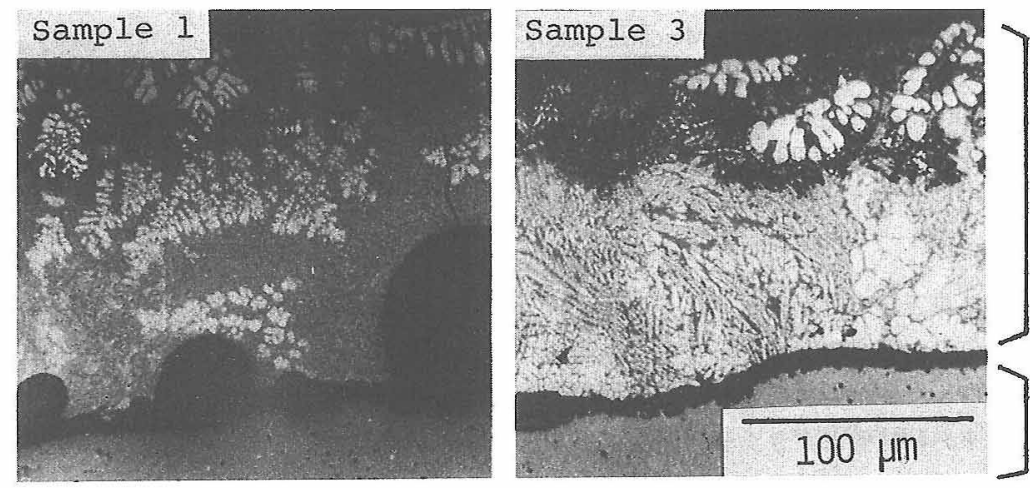

Mixed layer of $\mathrm{Cu}_{2} \mathrm{O}, \mathrm{CuO}, \mathrm{Cu}$ and amorphous material<smiles>O[SeH2]</smiles>
$\mathrm{Si}_{3} \mathrm{~N}_{4}$ substrate

Fig. 1. Optical micrographs of sections of metallized layer.

示す。試料 1 でもほぼ同じ結果が得られた。Cu は接着 率中の結晶部で強度が高く，最高強度は金属銅の強度と 同じである. $\mathrm{Si}, \mathrm{O}$ 及び $\mathrm{Al}$ は接着㓮層中で $\mathrm{Cu}$ と逆の 変化を示す。試料 1 の場合（カオリン無添加）にも Si 及び $\mathrm{Al}$ が相当検出された．Sは検出されなかった。透 明層では $\mathrm{Si}$ ，高濃度の O 及び微量の $\mathrm{Cu}$ が見られ， $\mathrm{Al}$ はほとんよ゙ない。

以上の観察から，基板直上の透明層はクリストバライ 卜，接着風層中の大きな結晶は金属銅，微細な結晶は金 属銅が酸化銅，マトリックス部は $\mathrm{Si}-\mathrm{Al}-(\mathrm{Cu})-\mathrm{O}$ よりな る非晶質物であると考えられる。

また，接着剤焼き付け中に起こる変化は次のように推 定される，硫化銅のみの場合，溶融と同時に分解して酸 化銅になるが，発生する $\mathrm{SO}_{2}$ ガスの還元作用により，
以上のごとく，本メタライズ法は空気中における加熱 及びそれに引き続く簡単な還元処理のみからなることを 特幑としており，窒化ケイ素セラミックスの利用に際し て十分に役立っものと思われる。

謝 辞 本研究の遂行に当たり，X線回折を担当された当 所第 4 部・門田正胤技官及び EPMA を担当された同若林 肇 技官に感謝いたします。

\section{文献}

1）江田儀弘, 門田正胤，坂田 真, 大工試季報，16，57-60 (1965).

2）江畑儀弘，木下 夹，門田正胤，北岡猛志，ibid,， 19, 51-56 (1968).

3）江畑儀弘, 樋端保夫, 植月倫夫, 小頼三郎, 片岡長正, ibid, , 30, 9-14 (1979).

4）江畑儀弘, 速水諒三, 木下 実, 工業材料, 30, 85-93(1983). 